\title{
FONTES QUATROCENTISTAS PARA A GEOGRA- FIA E ECONOMIA DO SAARA E GUINÉ
}

Os cronistas marcam no Cabo de Nāo o têrmo inicial dos descobrimentos portuguêses, o que nāo significa que se nāo navegasse para além, embora sem dobrar correntemente o Bojador. Econômico-geogràficamente entramos no Saara e, mais ao sul, na Terra Verde ou Guiné. Deixam de nos servir muitas das fontes que utilizámos para Marrocos, e surgem outras, de caracteristicas di. versas.

Para o Sul do Cabo de Nāo pode dizer-se que se nāo realızaram conquistas e ocupações permanentes, no século XV e primeira metade do XVI. Uma ou outra feitoria, um ou outro castelo, rarissimos, nāo desmentem a afirmaçāo geral. Agora, a faina de descobrir insere-se na trama dos acontecimentos, ao passo que falta totalmente no que se reporta a Marrocos. Sem dúvida, os intrusos lanceiam mouros, azenegues e negros, assaltam aldeias, roubam o que podem - como em Marrocos; mas descem do navio à praia, internam-se e regressam ao mar. Não são cavaleiros e escudeiros instalados em praças fortes; sāo homens de bordo que ocasionalmente calcurriam os caminhos de terra.

Ora, ao lado das reconstituições de gabinete, chegaram até nós alguns testemunhos dos próprios navegadores e mercadores - bem poucos, infelizmente. Por êstes relatos perpassa um espírito muito diferente do que anima as crônicas. Nāo sāo obras ofi ciais, encomendadas pelos círculos palacianos para exaltação de uma ideologia de interêsse para os que a patrocinam; além da frescura da visão direta, que o cronista nāo pode dar (pelo menos a cada passo), não só os olhos contemplam facetas da realidade diversas das que preocupariam o escritor áulico da côrte, como ainda há mais sinceridade em desvendar as intenções, uma expressão muito mais direta do individual, em contraste com a expressāo laboriosamente construída de pontos de vista que os dirigentes acham conveniente propalar, caracteristica da historiografia oficial. E tal contraste patenteia-se bem ao lermos nas crônicas a pormenorizada descrição de pretensas gestas guerreiras, enquanto na penumbra ou na obscuridade ficam as lides maritimas, as indicações geográficas e o registo dos costumes dos povos com que se entrou em contacto. 
A primeira em data das fontes que nos informam àcêrca das regiões ao Sul do Cabo Nāo é a Crônica da Guiné de Gomes Eanes da Zurara. Ao publicá-la pela primeira vez, o Visconde de Santarém deu-lhe o titulo, que ficou consagrado, de Crónica do Descobrimento e Conquista da Gruiné; mas Duarte Leite, José de Bragança e Costa Pimpāo estabeleceram, com base nos dizeres do exergo e na referência que o próprio Zurara lhe faz na Crônica do Conde $D$. Duarte, que o seu verdadeiro título é Crônica dos Feitos da Guiné - o que, já por si, traduz intuito bem diferente. A carta de Zurara a D. Afonso V, que anda anteposta à Crônica, e o explicit desta datam-na de 1453. Sāo evidentes, porém, sinais de redaçāo posterior à morte do Infante $D$. Henrique; poderia supor-se que se trata de interpolações e emendas ao texto primitivo, mas o problema é, na realidade, mais complexo. A análise interna da obra revelou a Costa Pimpāo que, tal como chegou até nós, deve consistir na cerzidura de duas obras diferentes: uma, a Crónica dos Feitos de Guiné própriamente dita, e a outra, uma Crónica ou Livro dos feitos do Infante D. Henrique, donde teriam sido aproveitados alguns capitulos e outros resumidos; a primeira teria sido escrita talvez em 1463-1464 (em quälquer caso antes de 1468, data da Crónica do Conde D. Duarte de Zurara, e depois de 1460 , dada da morte de $\mathrm{D}$. Henrique); a segunda remontaria a 1453 (a ela pertencendo a carta ao rei e o explicit da Crônica da Guiné atual), tendo sido começada por volta de 1452. A combinação das duas crônicas deveria imputar-se a um copista inepto, que as teria cerzido, alinhando-as temporalmente (aliás, de maneira desastrada), já morto o cronista e até talvez D. Afonso $V$ (1). As investigações de Duarte Leite fortaleceram a idéia de que a Crônica da Guiné resultou da fusāo de dois trabalhos diferentes. Mas, para êste investigador, a verdadeira natureza da obra a que pertenceram os capítulos cerzidos à Crônica dos feitos de Guiné é a de Panegítico, que dataria de depois da morte do Infante; a Crônica teria sido começada antes de 1460 e até de 1458 (alguns anos depois de 1451), mas terminada até 1465 (em todo o caso depois da morte de $\mathrm{D}$. Henrique); e o próprio Zurara é que teria fundido o Panegírico e a Crónica (2). Parece-me de aceitar a atribuição ao cronista, e nāo a um tardio compilador inepto, do trabalho de enxertar na Crônica trechos e resumos do Panegitico ou Crônica dos feitos do Infante. Quanto à data do Panegirico, nầo julgo o problema já totalmente 'resolvido. Costa Pimpāo nāo conseguiu alinhar qualquer argumento de pêso para a realizaçāo

(1). - Álvaro da Costa Pimpão: A "Crônica dos feitos de Guince" de Gomes Fanes de Zurara e o manuserito cortez - d'listrees. Lisboa, 1939; A "Crónica dos feitos de Guince", as minhas "tesces" e as "tesses" do Duarte Icite (Revista Biblos, vol. XVI1, tono II, págs. (66)-69(i), Coimbra, 1941.

(2). - Duarte Leite: Ãcêrca dà "Crônica dos feitos de Guinee". Lisboa, 1911, Um crítico da Crônica da Guino, Coimbra, 1942. 
de obra dêsse gênero antes da morte do Infante. Não será, porém, possível aduzí-lo? A explicaçäo poderia talvez ser a seguinte: Alfarrobeira dera-se em 1449; D. Henrique era severamente verberado pela sua atitude com o irmāo, o próprio rei nāo escapava às censuras, e o partido de D. Pedro nāo se extinguira totalmente (em Zurara mesmo encontramos referência a "outras vozes muyto contrairas daquestas que ataa aquy razoey"). E', pois, natural que o rei encarregasse Zurara da Apologia (no pleno sentido da palavra) do tio e que êste recompensasse o escriba com o título de comendador de Alcains em 1452. Nāo nos devemos esquecer de que a Regência é o reatar do conflito social de 1383-1385 - a luta entre as classes urbanas e a nobreza - e que D. Henrique representou presumivelmente a política da nobreza. Em 1449-1450 Zurara compôs (ou antes, re-compôs) a Crônica da Tomada de Ceuta, destinada já a apagar a figura do Infante D. Fedro, a exalçar a figura do Infante D. Henrique e a fortalecer a consciência expansionista-guerreira. A nobreza triunfante em Alfarrobeira carecia de criar o mito de uma grande personagem que fizesse olvidar o Infante das sete partidas e da "Virtuosa Benfeitoria"; necessitava de lhe arrancar os louros da expansāo maritimo-comercial. A corroborar o que pode deduzir-se quanto à dataçāo destas imposições do momento está a análise interna do capitulo $\mathrm{V}$ da Ctônica da Guiné que mostra que nele só se referem fatos até 1451 inclusive; ora, se escrito depois da morte de D. Henrique, deveria referir pelo mienos a tomada de Alcácer-Ceguer (1458). Por outro lado, contraditoriamente, a carta de Zurara ao rei - como mostrou Duarte Leite - tem todos os visos de escrita depois da morte de D. Henrique.

O problema ainda se complica, porque a Crônica dos feitos de Guiné nāo deve passar de remodelaçāo de uma crônica anterior, cujo autor é Afonso de Cerveira, a que o próprio Zurara alude freqüentemente dando-nos a impressão de que se limita a decalcá-la e ajustá-la a outros fins. Desconhecemos tal Crônica e desconhecemos o seu autor. Joāo de Barros, na Década I da Ásia, identifica-o com um Afonso de Cerveira que depois de 1485 era feitor em Benim, e de cujas cartas o cronista de quinhentos teve conhecimento parcial. Baseado neste passo de Barros, aventou José de Bragança a hipótese de que Cerveira, apaniguado de $\mathrm{D}$. Pedro, teria embarcado para África entre a desgraça do Regente e a batalha de Alfarrobeira, indo, mais tarde, dai para Benim (3). Sabemos, por documentos das chancelarias, da existência de outro Afonso de Cerveira, escudeiro criado do rei D. Duarte e recebedor do almoxarifado da Guarda em 1437 e 1438; êste Afonso ti-

(3). - Introdução à Crônica da Guinê (İđição de 1937, Pôto), vol. I, pág. XXXIX. 
nha um irmāo Joāo Cerveira que vivia em 1446, quando aquêle já estava finado (4). De um Afonso de Cerveira, almoxarife régio em Lamego, diz-nos uma carta de $7 \mathrm{~d}$ z agôsto de 1456 que fôra morto nessa cidade por um criado do Infante D. Henrique, João Homem, em 1441 ou 1442 (5); é muito provável que se trate do anteriormente recebedor da Guarda. Por conseguinte, nāo é o Afonso de Cerveira recebedor e almoxarife o autor da. Crônica que Zurara copiosamente utilizou (6). Contra a hipótese de José de Bragança, nāo vê Duarte Leite qualquer razāo para identificar o feitor de Benim (que o podia ser desde 1476) com o cronista do mesmo nome; mais ainda: Duarte Leite avança até que Cerveira já era falecido quando Zurara escreveu, "pois se vivo, $\dot{e}$ inverossimil que o cronista lhe tomasse sem cerimônia o grosso da sua obra"; na identificaçāo de Barros e Bragança, Cerveira teria sobrevivido à morte do seu plagiador (1474).

Fela análise da Crônica dos feitos de Guiné de Zurara conse.guiu Duarte Leite apurar que a Crônica de Cerveira devia constar de dois livros, dos quais foi integralmente escrito o primeiro, ficando por escrever ou por acabar o segundo. O primeiro livro narrava os acontecimentos até 1448 inclusive, devendo terminar neste ano: efetivamente, o balanço das caravelas enviadas e léguas percorridas, interpolado no capitulo LXXVIII da Crônica da Guiné, conduz-nos precisamente até essa data. A Crônica de Cerveira devia ser mais minuciosa do que a de Zurara, porquanto por três vêzes êste cronista declara que omite descrições ou transcrições do seu antecessor (7). Supôs José de Bragança, e, ao que se me afigura, com muita félicidade, que Afonso de Cerveira deve ter sido cronista do Regente; na sua Crônica é muito possivel que a iniciativa das principais viagens estivesse atribuida a D. Pedro; Zurara posteriormente apagaria o nome execrado do filho segundo do Mestre de Aviz e substituí-lo-ia pelo de D. Henrique (como ainda claramente se percebe em certas passagens) (8).

Qual a personalidade de Afonso de Cerveira e caracteristicas da sua obra? É muito difícil responder, É razoável, no entanto, conjecturar que nāo era navegador nem escrivāo de bordo, e que, por isso, nunca visitou as regióes de que fala. Na realidade, o cômputo das distâncias em léguas vem constantemente errado, de maneira grosseira, as fainas marítimas nāo parecem constituir o tema

(4). - Carta de quitação de 8 de setembro de 14t6 (Bocumentos das Chanbelarias reais relativas a Marrocos vol. I pigs. 331-9); ef. Idem, pág, $170)$.

(5). - Carta de 7 de agôsto de 1456 (rdem, vol. II, pág. 516).

(6). - Costa Pimpão: A "Crônica dos Fuitos da Ginee", págss. 1-2. Duarte Leite: Acêrca da "Orônica", púg. \$1.

(7). - Duarte Leite: ob. cit. págs. \$8-91.

(8). - José de Bragança: Notas à Crônica da Guiné. edição de 1937. Pôrto. Cf. Documentos sobre a dixpansão Portugutsa, vol. II, cap. III. 
central (deformaçāo aliás atribuivel ao épico Zurara), as descrições sāo vagas e, em especial, as que se reportam à flora e fauna "nāo parecem feitas de visu, atento o exagêro das dos animais" (9). Obra de gabinete, em suma, elaborada sôbre testemunhos orais e anteriores relatos escritos parciais.

A perda da Crônica de Cerveira, fonte quase exclusiva da obra de Zurara, fere irremediàvelmente de incerteza o valor da Crônica dos feitos de Guiné que até nós chegou. E, o que é também importantissimo: a Crônica de Zurara é trabalho de segunda māo, que nada indica o refundidor tenha melhorado, antes parece ter deturpado; ora, como é provável que Cerveira escrevesse sôbre testemunho alheio e ncio tivsse visitado as plagas africanas, a Crônica da Guiné é, quanto ao conhecimento e descriçāo das regiões descobertas, obra de terceira māo, pois ignoramos como procedeu Zurara relativamente às passagens que consignam tal conhecimento no livro do seu predecessor. Eu sei, tem-se apresentado a Crônica da Guiné como patrocinada pelo Infante D. Henrique e elaborada sob a sua direção cientifica; tal assêrto nāo repousa, porém, em quaisquer bases documentais e, a ser verdadeiro, só atestaria o reduzido cabedal e interêsse científico do Infante. Efetivamente, a Crônica enferma de defeitos graves, é uma obra imperfeita - a mais imperfeita das de Zurara. Segundo as conclusões sólidas a que chegou Duarte Leite, vamos enumerar as suas principais características que para o caso nos interessam:

1.0 A Crônica da Guiné destina-se a narrar os feitos dos portuguêses em África, quer dizer, a ser uma crônica de ações guerreiras;

2.0 Nāo é, por tal razāo, uma crônica dos descobrimentos;

3..$^{\circ}$ As distâncias que aponta estằo tôdas erradas por forte excesso (que vai de $32 \%$ a $60 \%$ pelo menos);

4. ${ }^{\circ}$ Raras vêzes aponta as distâncias;

5.0 Omite frequientemente as datas de partida das viagens e nunca refere as datas de regresso;

6. Contradiz-se no número total de navios que foram à Guiné até 1446;

7.0 "Poupa-se em nomear os lugares descobertos, pois em cêrca de 300 léguas de costa apenas menciona 11 nomes portuguêses, quando o mapa de André Branco de 1448 traz mais de 34 no mesmo espaço";

8..$^{\circ}$ É muito pobre de informaçães no que respeita à maneira como se organizavam as expedições;

9.0 Nunca fala da arte de navegar;

(9). - Duarte Leițe: ob. cit., páłs. 91-2. 
10.0 As descrições dos lugares são inacreditàvelmente sumárias;

11.0 Quase nada diz do comércio com os nativos, nem da vida econômica dos povos africanos (10).

Em face de tais caracteristicas, temos de reconhecer que as perplexidades se amontoam, ao pretendermos utilizar a Crônica da Guiné para estabelecer o estado econômico e social das populações com que os portuguêses entraram em contacto. Dificuldade basilar: a identificaçāo dos lugares a que aportaram, cujo nome o cronista em geral omite, cuja distância de pontos conhecidos raro refere e, se o faz, com certeza erradamente. Dêste modo, temos muitas vêzes de nos servir das pobríssimas descrições para identificar os lugares, por comparaçāo com as descrições de outras fonles, o que torna muito conjecturais as referências que colhemos em Zurara. Esta dificuldade aumenta de intensidade à medida que caminhamos para o sul; fato primacial: a Crônica nāo indica qual o têrmo último das viagens até 1448 (não o localiza), o que suscita múltiplas hipóteses e nos lança em novos embaraços. Há a certeza de que a exploraçāo durante a Regência abrange o Rio Senegal, o Cabo Verde, o Cabo dos Mastos; com tôda a probabilidade engloba o rio Gâmbia e estendeu-se mais para além, até onde? É provável que fôssem descobertos os rios de Casamansa e o Cabo Roxo, e talvez as caravelas chegassem ao rio de S. Domingos ( $\mathrm{Ca}-$ chéu). Antes das investigações de Duarte Leite, seguido por Damiāo Peres, aceitava-se que os portuguêses visitaram antes de 1448 o rio Geba e até o Rio Nuno, ainda mais ao Sul; mas esta interpretaçăo revelou-se frágil (11). Ao lado desta dificuldade basilar da identificaçāo dos lugares, uma limitaçāo de enormes consequiências: a insuficiência de informações geográficas e econômico-sociais, resultado sob́retudo da atitude de fâmulo da nobreza e homem de arquivo, que só vê a gesta guerreira e despreza a busca do proveito e a atividade de mercadejar. E, em terceiro lugar, uma característica que nāo devemos esquecer: o cronista nāo viu as regiões de que fala.

Quando transitamos para a segunda em data das fontes que se reportam ao descobrimento da Guiné o panorama muda integralmente. As Navegações de Alvise da $\mathrm{Ca}$ ' da Mosto são obra de um navegador e mercador, que as escreveu entre 1456 (ano da sua segunda viagem) e 1483 (presumivel ano da sua morte). É muito natural que as Navegações se baseiam em apontamentos de bordo, tirados durante as viagens de 1455 e 1456 à Guiné; nāo sabemos, porém, se foram redigidas ainda em Portugal, até 1463 (1'de fevereiro: data da partida para a Itália), ou se já o foram na pátria

(10). - Duarte Leite: Ảcêrca da “Crônica dos Feitos de Guinee”, Lisboa, 1941. (11). - Documentos sôbre a Expansão Portuguêsa, vol. 1.I, cap.' III. 
pouco depois do regresso: Andrea da Mosto, seu principal biógrafo, inclina-se para a primeira hipótese. A biografia de Cadamosto elucida-nos bem sôbre as caracteristicas da sua obra. Como data provável do seu nascimento em Veneza, aponta-se o ano de 1432; pertencia a uma família patrícia veneziana ativamente interessada no comércio. Muito novo, Alvise entrou na vida de negócios, e já aos treze anos viajou à Barbária e no ano seguinte a Creta. Como "besteiro nobre" foi na esquadra de comando de Contarini a Alexandria em 1451, e no ano seguinte partiu para a Flandres nas galés da carreira, regressando em fins de 1453. Para a Flandres partiu de novo em agôsto de 1454, mas ficou em Lagos. Depois da estadia de oito anos em Portugal, regressou a Veneza e negociou em produtos das Canárias, exportou castanhas para Alexandria e malvásia e sêda para Inglaterra; exerceu vários cargos públicos, foi encarregado de missões diplomáticas e comandou as galés que iam ao Egito comerciar (12).

Esta vida dá-nos o homem. Não é o conservador de um arquivo, um homem de biblioteca; nāo depende de reis nem de nobres, nāo foi oficialmente encarregado de qualquer crônica destinada a fins oficiais; a sua mentalidade nāo é a do cavaleiro ou escudeiro, para quem o mister é o exercício das armas e o fito o acrescentamento da honra e estado. É o homem que viajou largamente, conhece a Itália, o Egito, Creta, o Norte da África, a Flandres, Portugal, a Guiné: horizonte cosmopolita. E hábitos de pensar em escala cosmopolita também. Conhecimento direto, vivido, da realidade. Espírito voltado para as considerações do proveito - do lucro - atento às possibilidades comerciais, ao quadro da vida econômica: naturalmente, um homem assim observa com atençāo os costumes das gentes com que contacta, procura saber como se organizam, o que produzem, se trocam ou vendem, o que comem, e como se vestem.

- Não estamos bem elucidados àcêrca das condições em que veio para Portugal e resolveu navegar para a Guiné. Declara Cadamosto que, ao passar por Lagos a caminho da Flandres, foi seduzido pelos lucros que os portuguêses lhe asseveravam garantia o comércio africano. Nčo é, porém, improvável que já partisse de Veneza com a idéia de vir a Portugal com uma missāo relacionada com a procura de especiarias na costa ocidental de África (13). Seja como for, é certo que em 1455 embarcou numa caravela, fêz escala pelas ilhas de Pôrto-Santo e Madeira e arquipélago das Canárias, navegou para o sul, passando o Cabo Branco e a Ilha de Arguim, visitou a foz do rio Senegal e o país de Budomel, dobrou o

(12). - Para a biografia de Cadamosto seguimos o Apendice e a Le Navigazioni Atlantiche (Edição Rinaldo Caddeo, Milão 1929), que sumaria as investigações de Andea da Mosto.

(13). - A Expansão Quatrocentista portuguêsa (Lisboa, 1944). 
Cabó Verde, esteve no país dos barbacins e serrenos e chegou ao Gâmbia. Na segunda viagém, do ano seguinte, Cadamosto e Antoniotto Uso di Mare teriam descoberto o arquipélago de Cabo Verde, passado as Duas Palmas e o Cabo Verde, estanciado na regiāo do Gâmbia e continuariam para o sul, dobrando um cabo, descobrindo um rio de razoada grandeza e depois o rio Casamansa; descobriram em seguida o Cabo Roxo, o Rio de Santa Ana, o Rio de S. Domingos e finalmente o Rio Grande (Geba), avistando e visitando o arquipélago dos Bijagós.

O valor histórico do testemunho do veneziano ter sido acer. bamente contestado. Nele acreditaram Valentim Fernandes, no princípio do século XVI, e Damiāo de Góis em meados do mesmo século; mas ignoram-no ou recusaram-se a utilizá-lo os outros cronistas da expansāo, e nessa mesma éra de quinhentos Pedro Mártir de Anghiera acusou violentamente Cadamosto de lhe ter roubado a sua narrativa dos descobrimentos: acusação totalmente injusta, pois o veneziano era já morto quando êstes se deram e que repousa no simples equívoco de, na ediçāo dos Paesi nuovamente ritrovati, as cartas de Pedro Mártir seguirem as relações de Cadamosto sem nome do autor. Modernamente, muitos investigadores rejeitam que Cadamosto tivesse descoberto o arquipélago de Cabo Verde e alguns acoimam até de falsidade tôda a segunda viagem, que nāo passaria de fictícia, cerzida sôbre os relatos das viagens de Diogo Gomes e outros navegadores. É êste um ponto fundamental para os objetivos que nos propomos. Vamos, por isso, examinar as alegações contra Cadamosto, tais como as compendia Armando Cortezāo:

1. ' Cadamosto nā́o descobriu nem nunca esteve no arquipélago de Cabo Verde porque:

a) Fala de um rio largo na Ilha de Sant'lago; ora nesta ilha nāo existe qualquer rio nem sequer ribeira;

b) Diz que por alturas do Cabo Branco foi assaltado por vento furioso de sudoeste, durante duas noites e três dias, indo parar às ilhas de Cabo Verde; ora, como estas ficavam precisamente a sudoéste, é impossivel que com o vento lá tenha ido ter: logo, näo sabia sequer onde as ilhas ficavam;

c) Diz que partiu de Lagos em princípios de maio e que chegou a Sant'Iago no dia de Sāo-Felipe e Sant'Iago; impossivel, pois êste é o 1 de maio.

2.0 A primeira viagem de Diogo Gomes e a segunda de $\mathrm{Ca}-$ damosto teriam sido no mesmo ano e ambos se vangloriam de ser os primeiros a estabelecer relações com os indigenas e com o rei Batimansa; "ora isto nāo é natural, e muito menos que nenhum dêles fale da viagem do outro".

3. 0 Descreve Cadamosto a admiraçāo dos indigenas do Rio Geba ao verem caravelas, dando a entender que era o primeiro na- 
vegador que visitava essas paragens; ora, já lá tinham estado pelo menos Nuno Tristão e Estevāo Afonso (14).

Quase tôda estâ argumentaçāo assenta em premissas erradas. O terceiro argumento fica destruido pelo fato de Duarte Leite e Damičo Feres terem demonstrado que Nuno Tristāo morreu no rio Gâmbia e não o Geba ou no rio de Nuno; por outro lado, Estevāo Alonso deve ter estado no rio de Casamansa e não mais ao sul, consoante noutro trabalho procuramos mostrar (15). A existência de um rio na ilha de Sant'lago nos séculos XV e XVI é atestada pela Navegaçāo de Lisboa a Saão Tomá (1553) escrita por um pilôto português anônimo, e é-o igualmente pela toponimia pois a primeira povoação da ilha se chamou da Ribeira Grande. Não é verdade que Cadamosto diga que foi parar ao arquipélago de Cabo Verde com vento de sudoeste; o que afirma é que, para năo ter de voltar para trás, sz fêz na volta do oeste e noroeste, para costear o vento contrário e se aquentar, subentendendo-se que navegou em seguida com rumo ao sul. Quanto à data da partida de Lagos, há incerteza nas edições, de modo que em tal êrro não é lícito àssentar conclusāo tão grave como é a da faisidade de Cadamosto. Lopes Lima, baseado na sua experiência pessoal como oficial da marinha que fêz demoradas estações no arquipélago, contestou que do alto da ilha de Boavista se pudesse (como afirma Cadamosto) avistar duas ilhas ao sul; mas Sena Barcelos, caboverdeano e também baseado na sua experiencia pessoal, confirma a afirmaçāo de Cadamosto.

Não pode ainda considerar-se resolvido o problema do descobrimento das ilhas de Cabo Verde (16), e por isso, mostrado que nāo há na narrativa do veneziano a tal respeito falsidades decisivas, nāo consideraremos por mais tempo essa questāo. Vejamos pròpriamente a viagem à Guiné. Cadamosto engana-se ao contar que, depois de largar do rio de Casamansa, chegou ao rio de Santa Ana, porquanto êste é ao norte e não ao sul daquale (17). O problema fundamental é o da comparação e possível relação das duas viagens, de Cadamosto e Diogo Gom?s, no mesmo ano de 1456. Entre as duas narrativas há diferenças importantes. Em primeiro lugar, Cadamosto estanciou no Rio Gâmbia na viagem de ida, ao passo que Diogo Gomes o fêz na de regresso. Em segundo lugar, o português chegou ao rio Fancaso. que o veneziano năo

\footnotetext{
(14). - Armando Cortezão: Subsidios para a historia do Descobrimento da Guiné e de Cabo Verde (Boletim da Agência Geral das Colonias, n. ${ }^{\circ}$ 76, outubro de 1931), p. 36-8.

(15). - Documentos sôbre a Expansão Portuguêsa, vol. II, cap., III.

(16). - No 3.0 vol. dos Documentos sobre a Expansão, pronto desde 1947 mas ainda não publicado devido a dificuldades editorials, apresentamos uma solução bastante plausível.

(17). - Damião Peres: História dos Descobrimentos (Pôrto, 1944), págs. 103-4.
} 
visitou (18). Em terceiro lugar, Diogo Gomes, enquanto permaneceu no Gâmbia, esteve em Cantor, o que aconteceu com Cadamosto. Em quarto lugar, as descrições da estada no rio Geba nāo coincidem: Diogo Gomes fala de que os mouros trouxeram malaguêta, panos de algodāo e dentes de elefante, ao passo que Cadamosto (que nunca omitiria tais referências) diz que obteve só uns pedacitos de ouro. Mas as próprias circunstâncias das relações com o Batimansa sāo diferentes: o futuro almoxarife de Sintra encontrou-se pessoalmente com o rei na margem do rio e recebeu dêle três negros em presente, e depois visitou a sua residência, acabando o chefe indigena por se mostrar interessado na religiāo cristā; ora Cadamosto limitou-se a enviar um presente ao Batimansa e a comprar alguns escravos e um pouco de ouro. $O$ veneziano nāo reivindica, portanto, a primazia nas relações diretas com o rei, pois nāo fala que as estabeleceu ou tentou estabelecer. Não havendo pois, contradiçāo entre os dois relatos, e sendo diferentes, as cousas devem-se ter passado assim: 1, ${ }^{\circ}$ Cadamosto sobe o Gâmbia, envia um presente ao Batimansa e comercia com os negros do seu reino; $2 .^{\circ}$ Diogo Gomes trata pessoalmente a paz e comércio com o Batimansa.

Se as considerações que precedem sāo corretas e relevantes, nāo há razão para duvidar da segunda viagem de Cadamosto (19), como ninguém duvidou da realidade da primeira. Mais ainda. Das relações do século XV são as duas de Cadamosto arquitetônicamente as mais perfeitas, as mais lògicamente ordenadas; sāo também as mais precisas e minuciosas, sem dar lugar a dificuldades de localizaçāo, como as de Zurara e Diogo Gomes. Os erros que nelas se relevâm sāo mínimos, os cálculos das distâncias têem uma aproximaçāo que só o Esmeraldo excederá. Nenhuma das outras revela o mesmo sentido da natureza, as mesmas capacidades de observaçīo, que só serāo ultrapassados em alguns trechos da coletânea de Valentim Fernandes. Estas características, conjugadas com o que conhecemos da personalidade de Cadamosto, conferem quase a certeza de que o veneziano escreveu sôbre o que viu, com uma atitude mental de curiosidade pela flora e fauna, pelos costumes, crenças e formas de organizaçāo dos povos, que nāo encontram a essa data paralelo em Portugal.

A conclusāo análoga chegaríamos se comparássemos as $\mathrm{Na}$ vegações de Cadamosto com a de Pedro de Sintra. Estas são muito mais concises e mais pobres de dados sôbre a natureza e os indígenas, quase sêca enumeraçāó dos lugares percorridos por aquêle navegador até 1462. Declara Cadamosto que um seu amigo acom-

(18). - A sua narrativa e suficientemente minuciosa para que seja impossível conceder tal omissão. Uma omissão $e$, 10 jnvós, possivel na relação de Diogo Gomes.

(19). - O mais recente historiador dos Descobrimentos, Damião Peres, aceita-a sem sequer a discutir. Ob. cit. págs. 102-104. 
panhou o capitāo Pedro de Sintra e no regresso "il predetto mio amico dismontò in casa mia il quale mi diede in nota di punto in punto tutto il paese che avevano discoperto, e li nomi che gli aveano messo, 'e le starie come stavano"; ora êste amigo era um jovem português que viajara com Cadamosto à Guiné como escrivão de bordo, segundo nos informa o veneziano (20). É, por conseguinte, muito provável que Cadamosto se limitasse a reduzir a escrito o relato oral ou até que reproduzisse simplesmente, talvez polindo-o, o diário de bordo na posse do escrivão ou mesmo por êste redigido. "Seja como for, a Navegaçāo de Pedro de Sintra é obra escrita ou ditada por um escrivão da época henriquina e, como tal, um excelente padrāo dos diários de bordo, ao começar a segunda metade do século XV" (21). A Navegaçāo descreve-nos a costa africana desde o Rio Grande (Geba) até a Mata de Santa Maria.

Numa coletânea de obras sôbre a expansāo portuguêsa, compilada por Valentim Fernandes em 1506-1507, vêem insertos três textos latinos com os títulos De prima iuentione Gujnee, De insulis primo inuentis in mat oceano ocidentis, De inuentione insularum de Açores. Lê-se ao começo da primeira relaçāo: "Qualiter - fuit inuenta Aethiopia australis quae Libia inferior nuncupatur ultra descriptionem Ptolomei quae Agizimba nominabatur nunc vero Guinea $a b$ inuentoribus Portugalensibus nuncupata est usque hodiernum diem quam inuentionem retulit Dioguo Gomez almoxeriff palatii Sinterij Martino de Bohemia incliti militi abmano" (22). Trata-se por conseguinte, de uma relaçāo do descobrimento da Guiné redigida em latim sôbre o relato - oral ou escrito? O mais provável é oral - que dêle lhe fêz um navegador henriquino, Diogo Gomes.

Martin Behaim nasceu em Nuremberg em 1459 e aprendeu os rudimentos de cosmografia; em junho de 1484 veio para Portugal e aqui casou, talvez em 1488, com uma filha de Josse de Hurtere, natural de Bruges, capitāo donatário do Faial e Pico. Em 1492 encontra-se de novo na sua terra natal, onde constroi o célebre globo em que acumula ignorâncias e presunções eruditas e se vangloria de ter viajado com Diogo Cāo no descobrimento da África. Regressou a Portugal e morreu em Lisboa em 29 de julho de 1507.

Ignoramos a data da relaçāo de Diogo Gomes. Nāo é certamente anterior a 1485, ano em que possivelmente Behaim fêz uma

\footnotetext{
(20). - Teria Cadamosto utilizado jé os seus préstimos (inclusive as suas notas) para redigir o relato das duas viagens de 1455 e 1456 ou, pelo menos, de uma delas? A hipótese não é inverossímil.

(21). - Jaime Cortezão: A Carta de Pero vaz de Caminha (Rio de Janeiro, 1943), págs. 16-17.

(22). - Este incipit deve ter sido redigido por Valentim Fernandes, porquanto o próprio Martinho de Boêmia não se anunciaria como ínelito cavaleiro (Duarte Leite, ob. cit., pág. 14S).
} 
viagem á Guiné (23) e ano seguinte ao da sua vinda para Hortugal. Poderíamos supô-la anterior a 1492, ano em que Martim está de novo em Nuremberg, pois qualquer data posterior ao seu regresso a Fortugal dá já a Diogo Gomes idade muitíssimo avançada (ignoramos o ano da sua morte). Mas na Relaçāo lê-se: “... e Antônio da Noli pediu ao rei a capitania da ilha de Sant'Iago, que eu Diogo Gomes descobrira; e o rei deu-lha, e êle a conservou até morrer." Ora, a data da morte de Antônio da Noli talvez seja 1496 (24); logo a Relação é, pelo menos neste passo, posterior a 1495 (25). As suas circunstâncias também nos nēo sāo conhecidas. Sabemos tão só que Diogo Gomes era entāo almoxarife de Sintra, tendo abandonado possivelmente há longos anos as fainas marítimas. $O$ que na relaçāo é de fato do antigo navegador e o que deve imputar-se ao alemāo, nāo é fácil discriminar; as referências eruditas podem ser da pura responsabilidade de Behaim (26).

$\mathrm{Na}$ enumeraçāo e narrativa das navegaçōes até 1448 hả salientes discrepâncias entre o relato de Gomes-Behaim e a Crônica da Guiné. O almoxarife já devia estar velho e com a memória cansada quando sôbre o tema falou com o alemāo, e possivelmente as informaçôes que colliera oralmente a tal respeito nāo mereceriam extraordinária confiança. Há erros evidentes na relaçāo. Em todo o caso, os apontamentos de Diogo Gomes caracterizam-se por maior précisāo geográfica (indicando quase sempre os nomes dos lugares) do que a obra de Cerveira-Zurara. Mas nāo é comparável, sob êsse ponto de vista nem sob o da abudância de indicações naturalistas e etnográficas, aos relatos de Cadamosto. Quanto às suas características essenciais, pode dizer-se que a relação em análise está entre a Crônica da Guiné e as Navegaçóes do veneziano. Se fala em grande parte do que ouviu e nāo presenciou, Diogo Gomes narra também o que viu, as suas próprias viagens, baseia-se numa experiência pessoal, direta. Nāo é, decerto, o veneziano cosmopolita, que viajou por vários mares, ligado ao mais alto capitalismo europeu; mas é um navegador do Atlântico que sulca o golfāo, e homem de mentalidade essencialmente comercial: pois nāo foi para almoxarife quando já nāo podia navegar? A $R e$ laçāo revela-no-lo interessado no ouro, nos escravos e na malagueta, e em tôda ela perpassa o sôpro da ânsia de proveito (o que nāo quer dizer que se nāo refira também à evangelizaçǘo). E, além disso, como as Navegações de Cadamosto, nāo é uma obra oficial, é uma compilaçâo de apontamentos particulares.

(23). - Duarte Leite, ob. cit., pág. 148 (nota 165).

(24). - Sena Barcelos: Gubsidios para a História de Cabo Verde e Guine., págs. 51-2.

(25). - Fontoura da Costa: Cartas das Ilhas de Cabo verde, pág. 17.

(26). - Assim o supõe, e com razões, Duarte Leite. 
$\mathrm{Na}$ parte que podemos chamar etnográfica, a Relaçāo é assim de contiança, e continua para o sul as informações de Zurara, dispondo nós portanto, com o testemunho de Cadamosto, de dois testemunhos coevos e de visu sôbre as regiões, do Senegal, do Gâmbia e do Rio Grande (Gêba).

Apensa ao Itinerário do Dr. Jerônimo Munzer anda uma relaçāo, por êle redigida (consoante as suas próprias declarações), De inuentione Africae maritimae et occidentalis uidelicet Geneae per Infantem Heinticum Portugalliae. Não se tem prestado atenção a esta obra, considerando-se comumente que naao passa de reproduçāo da de Gomes-Behaim. Munzer, nascido em Feldkirch. em data ignorada, doutorou-se em medicina pela Universidade de Pavia em 1478, e residiu depois em Nuremberg, "onde exerceu a sua arte, obtendo ao fim de dois anos o direito de cidadāo". Visitou a Itália de novo em 1484-1485. Em 1494 partiu para a Fenínsula Ibérica na companhia de três mercadores alemāes, e esteve em Espanha e em Portuqal. Já em 14 de julho de 1493 escrevera de Nuremberg a D. Jočo II, sugerindo-lhe o plano de atingir a Índia pelo Ocidente, para cuja execuçāo lembrava Martim Behaim, que parece ter sido o portador da carta. A sua morte é de 27 de agôsto de 1508, na cidade de adopção (28).

A relaçāo de Munzer divide-se claramente em duas partes. A primeira narra os descobrimentos realizados em vida do Infante D. Henrique, a segunda informa-nos àcêrca do clima e mar, flora e fauna, produçôes e comércio, guerras e religiāo da Guiné, bem como àcêrca das ilhas de S. Tomé, Madeira e Açores. Esta segunda parte tem por fontes, segundo indica o próprio autor, um poema em verso heróico, de Cataldo Sículo, e os relatos orais dêste pregador do rei, de D. Joāo II (principalmente no que respeita à ilha de S. Tomé), de Conrado de Ratisbona, bombardeiro que esteve em África, de outros navegadores, de Josse Hurtere e da espôsa dêste. Tal descrição nāo localiza, excepto no que às ilhas concerne, os dados que nos fornece sôbre a Guiné (em sentido muito lato). A primeira parte enumera e narra as navegações de maneira muito próxima à da Relaçāo de Diogo Gomes, em nítido contraste com a Crônica da Guiné. Mas entre o texto de Munzer e o de GomesBehaim há diferenças que nāo sāo para desprezar, além de pequenas diferenças que atestam a pouca confiança que merece o manuscrito do segundo que até nós chegou. Indiquemos algumas:

a) Munzer indica que D. Henrique foi movido aos descobrimentos porque "os rendimentos paternos nāo chegavam para tão grandes despesas"; Gomes diz que foi "para sustentaçāo de seus nobres".

(28). - Basílio de Vasconcelos: "Itinerário" do Dr. Jerônimo Munzer (Coimbra, 1932), Introdução. 
b) Munzer declara que em 1415 alguns nobres que embarcaram em Lisboa para Ceuta foram arrastados pelas tempestades para a thl ha de Lançarote, desembarcaram aqui e, como nāo vissem ninguém, retiraram-se; segundo Gomes Behaim, D. Joāo de Castro em 1415 foi com uma armada e conquistou a Grā-Canária.

c) Munzer nāo cita Diogo Gomes entre os componentes da expediçāo de Gil Eanes, Lançarote, Nuno Tristāo e Gonçalo de Sintra às illhas de Tesslin, Nar e Tider, mas em compensação indica (o que Gomes-Behaim nāo faz) que os cativos foram em parte vendidos em Fortugal e em parte dados ao Papa e a outras pessoas.

d) Munzer nāo fala da viagem de Diogo Gomes de 1456 que é, por assim dizer, o centro da Relaçāo Gomes-Behaim.

e) Munzer fala só de uma viagem de Diogo Gomes, por mandado do rei, depois da morte de $\mathrm{D}$. Henrique, e dela relata só que em 12 dias chegou a Cabo Verde; deve ser confusāo com a viagem que Gomes relata como passada antes da morte do Infante.

f) Munzer nada diz àcêrca do descobrimento do arquipélago de Cabo Verde.

As omissões relativamente a Diogo Gomes sāo grave óbice contra a hipótese a nāo ser isso altamente provável, de que Jerônimo sumariou o que lera na Relaçāo de Gomes-Behaim, que lhe teria sido facultada pelo seu amigo e concidadāo ou pelo impressor de Morávia Valentim Fernandes. É ainda talvez estranho que Munzer não refira as suas conversas com Behaim ou com Fernandes, porquanto refere na segunda parte os seus informadores. Ter-se-ia servido de uma Relaçāo - hoje desconhecida e perdida - em que também se tivesse baseado Diogo Gomes ou Martim Behaim? A hipótese tem uma certa verossimilhança.

A Reiaçāo De Inuentione Africae maritimae et occidentalis é feita sobretudo do ponto de vista das relações da Guiné com Portugal e nāo tanto da realidade africana em si própria. Dá-nos o comércio dos portuguêses com essas regiões no reinado de D. Joāo II e as transformaçōes culturais, mais do que a própria economia e crenças nativas; mas apesar disso dela há a reter algumas indicações.

- O mais rico repositório de informações etnográficas sôbre a África Ocidental Setentrional é a coletânea de Valentim Fernandes o Alemāo. Êste impressor, natural da Morávia, veio para Portugal talvez em 1494 e aqui faleceu ẹm fins de 1518 ou princípios de 15i9. Conhecia alemaao, latim, português e castelhano. A partir de 1503 exerceu o lugar de tabeliāo público e corretor dos mercadores alemāes residentes em Lisboa. A sua atividade repartiu-se também pela impressāo, traduçāo, compilaçāo e até pela redação 
de alguns originais. Correspondia-se com Conrad Peutinger e com um mercador de Nuremberg (29).

Valentim Fernandes nāo é, portanto, o navegador ou o comerciante, mas também nāo é o cronista oficial, áulico da côrte. Mas está em relações com todos êstes meios. Ligado à "nova arte" da imprensa - essa arte nova que inicialmente serviu para difundir a cultura medieval e religiosa, como Lucien Febvre mostrou; suas preocupações culturais e até seus conhecimentos, sem fazerem dêle um erudito.e humanista no pleno sentido das palavras, encorporam-no nesse largo e complexo movimento de descoberta do homem e da natureza -do humanismo e da erudiçāo. No entanto, como corretor e tabeliāo dos mercadores, mergulhava na vida mercantil internacional. Horizontes cosmopolitas; uma funda curiosidade pelo desvendar de novos mundos, pelo conhecer de povos exóticos.

O chamado "Manuscrito Valentim Fernandes" constitui uma juxtaposiçāo, quando nảo amâlgama de fontes heterogêneas que o alemāo compilou, resumiu, completou e redigiu sem qualquer perfeiçāio ou sequer preocupaçāo arquitetônica. O códice nāo chegou, para mais, até nós em bom estado de conservaçāo; há desordem na foliaçāo, repetições, saltos, lacunas. Encontram-se nele indubitàvelmente as seguintes obras autônomas:

a) "Crônica da Guiné" de Zurara, resumo e transcrição parcial por Valentim Fernandes, acabado em 1506 (fols. 216 r.-269 r. ou págs. 133-186 da ed. A. Baiāo). Carece de todo valor como texto zurariano.

b) "Relações" de Diogo Gomes (em latim), de que acima tratamos.

c) "Êste livro é de rotear".

d) "Viagem de D. Francisco de Almeida, primeiro viso-rei da India" - caderno de bordo da nau S. Rafael, pelo escrivāo da feitoria Hans Mayr, 1505-1506. Só interessa ao conhecimento da Guiné pelas referências ao pôrto de Ale.

e) "Das ilhas de Dive" (Oceano Índico).

f) "Das ilhas do mar Oceano" - Canárias, Madeira, Açores, Cabo Verde, Sāo Tomé e anexas, 1506, redigido por Valentim Fernandes. Aproveita passagens de Zurara, Diogo Gomes, Cadamosto, mas a descriçāo vale sobretudo pelas abundantes informações colhidas de testemunhas de visu posteriores (assim, por exemplo, para Sāo Tomé e anexas, os relatos minuciosos de um marinheiro; Gonçalo Pires, que as freqüentara).

g) "A descriçāo de Ceuta por sua costa de Mauritânia e Etiópia pelos nomes modernos prosseguindo às vêzes algumas cou-

(29). - Biografia em: As Cartas das lihas de Cabo Verde de Valentim Fernandes, por A. Fontoura da Costa (Lisboa, 1939). 
sas do sertāo da terra firme" (f. I e 45-63v ou págs. 9 e 33-42 da ed.). Escrita em 1507, foi dada ao morávio por um Pero nāo identificado.

h) "De Arguim ilha e seu castelo e trauto e da terra firme dela e deserto dela e da cidade de Oadem e do sal e outros lugares e das gentes destas terras e desertos, e animálias, aves e ervas e árvores e assi dos costumes da gente dela. Escrita por mim Valentim Fernandes em Tomar estando el-Rei ali ano de 1506 aos 18 de Junho de palavra de Joam Rodrigues, reposteiro do dito Senhor que per aquelas terras foi enviado del-rei Dom Joam o segundo no ano de 1493 e naquele tempo esteve lá dous anos e despois foi lá per muitas vezes" (f. 64-88 ou págs. 42-64).

i) Descriçāo da Serra-Leoa e regiões circunvizinhas, sôbre informações dadas por Álvaro Velho, do Barreiro, com tôda a probabilidade o autor do Roteito da Primeira Viagem de Vasco da Gama; na torna-viagem da Índia, em 1499, Álvaro Velho, em vez de acompanhar o Gama a Lisboa, deve ter ficado por alturas do Rio Grande e estanciou na Guiné uns oito anos; de regresso a Portugal, forneceu a Valentim Fernandes uma descriçāo das regiões para o sul daquele rio (30), provàvelmente sob forma oral que o impressor reduziu a escrito.

j) Entre estas duas descrições, intercalam-se várias paginas onde há extratos de Zurara e Cadamosto mas também outros elementos que talvez façam parte dos relatos de Joāo Fernandes e Álvaro Velho.

Estas descrições que por comodidạde de designação reduziremos ao díptico Joāo Fernandes-Álvaro Velho cobrem todo o Saara ocidental e parte do central e a Guiné ou Terra dos Negros no sentido clássico do têrmo, isto é, a África Negra ocidental e setentrional, do Cabo Verde ao gôlfo de Guiné para além da Serra Leoa. Se as caravelas portuguêsas descobriram e exploraram metòdicamente, a partir de 1433, as costas da África Ocidental setentrional para o sul do Bojador, os exploradores, agentes reais e mercadores penetraram profundamente no sertāo da terra firme: em Uadam funcionou uma feitoria, os portuguêses freqü:entaram as feiras de Cantor e chegaram, na éra quatrocentista e na primeira metade do século XVI, a Gini e Tombuctu. As referências de Joāo de Barros sāo neste ponto corroboradas sem equívoco pelo conhecimento exato e preciso que as fontes portuguêsas revelam da topografia, povos, correntes e práticas comerciais, costumes. vida econômica e social, crenças e práticas e formas políticas do Deserto e da Terra Verde até o coração do continente. Nada de análogo, ou sequer de longe comparável nas outras fontes européias cristās. Em 1447 o genovês Malfante esteve no Tuat, sem

(30). - "Roteiro da I." viagem de V. da Gama", ed. Fontoura da Costa (Lisboa, 1940), preámbulo, págs. XI-XVII, 
conseguir avançar mais para o sul; da Terra dos Negros nāo obteve mais que informações vagas, muito vagas, e algo fantasistas; a carta que escreveu do Tuat interessa ao conhecimento dêste oásis e um pouco dos Tuareg: eis tudo (e já é bastante).

Alguns historiadores falam de uma viagem do florentino Benedetto Dei a Tombuctu entre 1469 e 1474. Na Cronaca di Benedetto Dei, códice da Biblioteca Nacional de Florença, lê-se: "Sono stato a Tambettu luogho sottoposto al Reame di Barberia fra terra e favvisi assai (affari) assai e vendesi panni grossi e Rasci e Ghurnelli con quella costola che si fanno in Lombardia" (31). Sócio da casa Portinari, cujos negócios abrangem a Europa e o Oriente, percorrera o Império Turco e todo o Levante, e visitará a França, Flandres, Alemanha e Suiça, até ser colocado à testa do Banco em Milāo (32). Nāo admiraria, por isso, que tentasse alcançar o grande mercado do ouro sudanês. Mas aquela referência é algo de completamente isolado, e nāo traduz nenhum conhecimento preciso sôbre aquela cidade ou o mundo negro - uma daquelas pequenas indicações que bastam para autenticar uma informação de tal monta. Nem sequer no ouro fala. Assim, a viagem do florentino năo pode acolher-se sem expressas reservas, e seja como for é inteiramente inútil para aprendermos seja o que for sôbre o Saara ou a Guiné (33).

As descrições de Joāo Fernandes e Álvaro Velho nāo encerram qualquer elemento de maravilhoso ou sequer de fantasia. Muito minuciosas, resistem à prova das pesquisas geográficas e históricas, confirmam ou sāo confirmadas pelas fontes muçulmanas, e revelam um pertinente interêsse pela complexidade da realidade indígena. Sāo mais ricas mesmo, sobretudo para a Guiné ocidental, do que Da África, terceira parte do mundo, de Joāo Leão dito o Africano, mouro que atravessou o Saara e visitou alguns reinos negros no comêço de Quinhentos, e mais tarde, cativo dos cristãos, reescreveu em italiano, em Roma, o relato das suas vastas deambulações (34). Da África completa harmoniosamente as fontes portuguêsas para as regiões menos iluminadas por elas: Saara setentrional e central e Sudāo central.

"Este liuro he de rotear s. de todo Portugal e de Galiza atee Sorlinga e Oexamte e das ylhas de Madeyra e dos Açores e de

\footnotetext{
(31). - Amat di San Filipo: Biografia doi viaggiatori italiani (1882) p. 154.

(32). - Idem, p. 152-6.

(33). - Paradoxalmente, autores como Th. Monod, geralmente avisados, aceitam sem rebuços a realidade histórice da viagem de Dei, todavia tão problemática, e rejeitam a das penetraçōes quatrocentistas e quinhentistas portuguêsas, perfeitamente corroboradas.

(34). - Deseription de PAfrique tierce partio du monde (1526), tradução Jcan Temporal, París, 1556; nova ed. Paris, 1830.
} 
Guynee", que ocupa as fols 292r a 315r do "Manuscrito Valentim Fernandes" constitui o primeiro roteiro português que até nós chegou. Mas outros anteriores devem ter existido, que se perderam ou estāo ignorados. "Êste livro é de rotear" indica sòmente os rumos e distâncias estimadas, sem descrições das terras e com apenas raras conhecenças. O próprio estilo - "sabe que..." - junto à simplicidade das indicações náuticas e ausência de preocupações geográficas, para não falar das etnográficas e comerciais, e - fato de terminar no gôlfo de Guiné levam a datar êste roteiro de circa 1480-1485. Um parágrafo que tem passado despercebido suscita certas dificuldades cronológicas: "Sabe que jazem as Antillias com o Ferro leste e oeste. $E$ ha na rota VII léguas largas. E estando nelas demorará as ilhás do Cabo Verde, s. a do Sal leste e oeste toma a quarta do Noroeste e sueste." Trata-se sem equívoco - dados os rumos e distância - das Antilhas na América Central. Ora a primeira viagem de Colombo é posterior de alguns anos à data atrás apontada. Teremos, visto isso, de atrazar a data do roteiro? Esta soluçāo coaduna-se pouco com a natureza do texto. Tratar-se-á, quanto àquêle parágrafo, de interpolaçāo? Ainda há que admitir terceira hipótese: é que estas frases de "Êste livro é de rotear" se integram no conjunto de indícios de um conhecimento pré-colombino das Antilhas, que uma passagem do próprio Colombo sugere e outras alusões tornam provável. $\mathrm{Pa}-$ rece-me dificilmente contestável que o roteiro em queștāo é anterior a 1485 .

Uns vinte anos mais tarde, Duarte Pacheco Pereira principiará um outro roteiro, que não chegará a concluir, de âmbito universal e muito outras preocupações e características: o "Esmeraldo de situ orbis", ou seja, o "de situ esmeraldo orbis" — do sitio verde ou maritimo do orbe, na feliz interpretaçāo do Dr. José Dentinho de um enigma que resistira aos investigadores mais sagazes. O "Esmeraldo" nāo é apenas um roteiro, nem Duarte Pacheco apenas um marinheiro. Nauta experimentado, encarregado de explorações transatlânticas para os lados da Flórida, e do metódico reconhecimento das plagas africanas, ao longo de Marrocos, do Saara e de Guiné, sim. Mas também chefe militar cujas vitórias fundaram o prestígio português no Oriente, capitāo, no fim de sua carreira, de São Jorge da Mina, humanista que conhece bem os geógrafos e cosmógrafos clássicos e medievais, além de outra literatura, homem desperto para as realidades e exigências do comércio. O "Esméraldo" é simultâneamente um compêndio de cosmografia e náutica astronômica que apresenta soluções novas e práticas, um roteiro muito completo no feixe de indicações de rumos, distancias, conhecenças e sinais, um compêndio de geografia comercial com elementos de geografia histórica. Mas seu in- 
terêsse e importância nāo reside sòmente na conexāo das matérias que sistemàticamente expõe, reside acima de tudo no espirito que o informa. Nāo é ainda o espirito científico, cujas demonstrações se desenrolam ùnicamente no plano racional-experimental sem a minima interferência de autoridades; ainda no "Esmeraldo" aparece, conquanto esporàdicamente, acessòriamente, o apêlo à autoridade como prova. Nāo é mais todavia o simples "ouvir dizer", o "mais ou menos assim", o argumento puramente livresco. Perpassa por tôda a ó̉ra de Duarte Pacheco a ânsia de precisāo, de mostrar pela experiência, de medir com suficiente aproximaçāo. Nāo se trata ainda de concatenar relações matemáticas, ou matemáticotactuais, de estabelecer uma teoria verificável da relidade física. Mas também já nāo se trata dessa literatura livresca ou fantasiosa, com a "Imago Mundi" de Pierre d'Ailly que depois de Marco Folo e outros reproduzia sem pestanejar as fábulas incriveis de Plinio e outras obras antigas e medievais. Sem dúvida no "Esmeraldo" fala-se nos "homens com cabeça de cāo" no interior da África e nas serpentes que se dissolvem na água; únicos passos que traduzem a continuaçè̀ da velha mentalidade. Mas, no conjunto, no "Esmeraldo" há o sentido da diferença entre o possivel e o impossivel. Há escrúpulo rigoroso na recolha dos dados (por nāo dispor de absolutamente seguros é que năo chegou a escrever a parte consagrada à África Oriental). Há esfôrço metódico de mensuraçāo exata e precisa, e nāo números ao acaso ou erros de $30 \%$, $40 \%$ e mais (como em Colombo e tantos outros).

Escrito de 1505 a 1508, o "Esmeraldo de situ orbis" de Duarte Pacheco Pereira representa uma revoluçāo cultural, de que nāo é aliás o único motor nem indicio: a passagem de uma cultura sem sentido do possivel e do impossivel, sem preocupaçāo pela medida, pela precisāo e exatid̄̄o nem utensilagem para as buscar, baseada no "mais ou menos assim" e no "ouvir dizer" inverificado e nos argumentos de autoridade (35), para o que poderiamos chamar o humanismo técnico: o sentido da precisāo e exatidāo, a preocupação pela medida, a busca de provas verificáveis (36).

\section{VITORINO MAGALHÃES GODINHO \\ (Centre National de la Recherche Scientifique. París).}

(35). - Vejam-se os estudos e ensaios de Lucien Febrre e Alcxandre Koyré.

(36). - Sôbre o "Esmeraldo", até hoje mal estudado, e sôbre a utensilaģem mental e a sensibilidade em Portugal nos séculos XV e XVI está Barradas de Carvalho a efetuar pesquisas segundo a orientaç̃o metodológica de Lucien Febvre.

O presente estudo, redigido em 1948 e agora apenas completalo nas páginas finais, assenta no exame direto dis fontes mas deve muito às análises e idéias de Duarte Leite, Teiga Simōes, José de Bragança, Jaime Cortesão. 